九州大学学術情報リポジトリ

Kyushu University Institutional Repository

\title{
The Development of Momi (Abies firma) and Tsuga( Tsuga sieboldii) Trees on the Basis of Root Growth
}

Yuruki, Tatsuro

University Forest, Faculty of Agriculture, Kyushu University

Setsu, Takao

University Forest, Faculty of Agriculture, Kyushu University

Aragami, Kazutoshi

University Forest, Faculty of Agriculture, Kyushu University

https://doi.org/10.5109/23948

出版情報: 九州大学大学院農学研究院紀要. 35 (1/2)，pp.43-49，1990-12. Kyushu University バージョン：

権利関係 : 


\title{
The Development of Momi(Abies firma) and Tsuga( Tsuga sieboldii) Trees on the Basis of Root Growth
}

\author{
Tatsuro Yuruki, Takao Setsu and Kazutoshi Aragami \\ University Forest, Faculty of Agriculture, \\ Kyushu University 46-11, Fukuoka 812, Japan.
}

(Received June 22, 1990)

\begin{abstract}
The development of a momi (Abies firma) and Tsuga (Tsuga sieboldii) forest was elucidated from a viewpoint of root growth. Estimation of the ages was very difficult for momi roots, because of the existence of the narrow and incomplete rings. It was supposed that most of the incomplete rings are not false rings but undistinguished normal rings. In tsuga roots, few incomplete annual rings were recognized. The growth of the taproots and stems of a momi tree was mutually related. These relations were also obscured in a tsuga tree. The habitat segregation did not occur between the momi and tsuga roots.
\end{abstract}

\section{Introduction}

Generally, momi trees grow on a gentle slopes and tsuga trees on a ridges or steep slopes, but both frequently coexist and form a momi and tsuga forest.

To date, many studies have been conducted on momi and tsuga forests respectively from the viewpoint of the habitat and development of a community. We have studied the development of momi and tsuga forest by the changes in the individual diameter rankings from the viewpoint of the mutual relation of both species (Yuruki et al., 1987a) (Yuruki et al., 1987b) (Yuruki et al., 1988). However, compared with the growth of stems, relatively little is known about the development of the root systems of momi and tsuga trees.

In the present paper, we have tried to clarify the development of a momi and tsuga forest from the viewpoint of root growth.

\section{Materials and Methods}

A natural momi and tsuga forest was investigated in compartment 29 of the Kyushu University Forest in Miyazaki Prefecture (latitude : 31" 22' N, longitude : 131' $10^{\prime} \mathrm{E}$, altitude $: 1050 \mathrm{~m}$, warmth index $: 82$, topography : middle of the east slope, inclination of slope : $20^{\circ}$, geologic bedrock : sandstone . clay slate - shale, soil type :moderatelymoist brown forest soil(BD)). Broad-leaved trees and suzutake (Pseudosasapurpurascens Mak.) coexisted in the momi and tsuga forest.

The ratio of momi trees to tsuga trees in the forest was 1 to 4 . Judging from the annual rings of the stumps, this forest was presumed to be a natural forest formed about 70 years ago. The undergrowth was poor, because broad-leaved trees and suzutake were removed in 1983.

The plot $(10 \times 15 \mathrm{~m})$ was established in the momi and tsuga forest in 1988. A momi tree and tsuga tree growing side by side in the plot were investigated. The stems of 

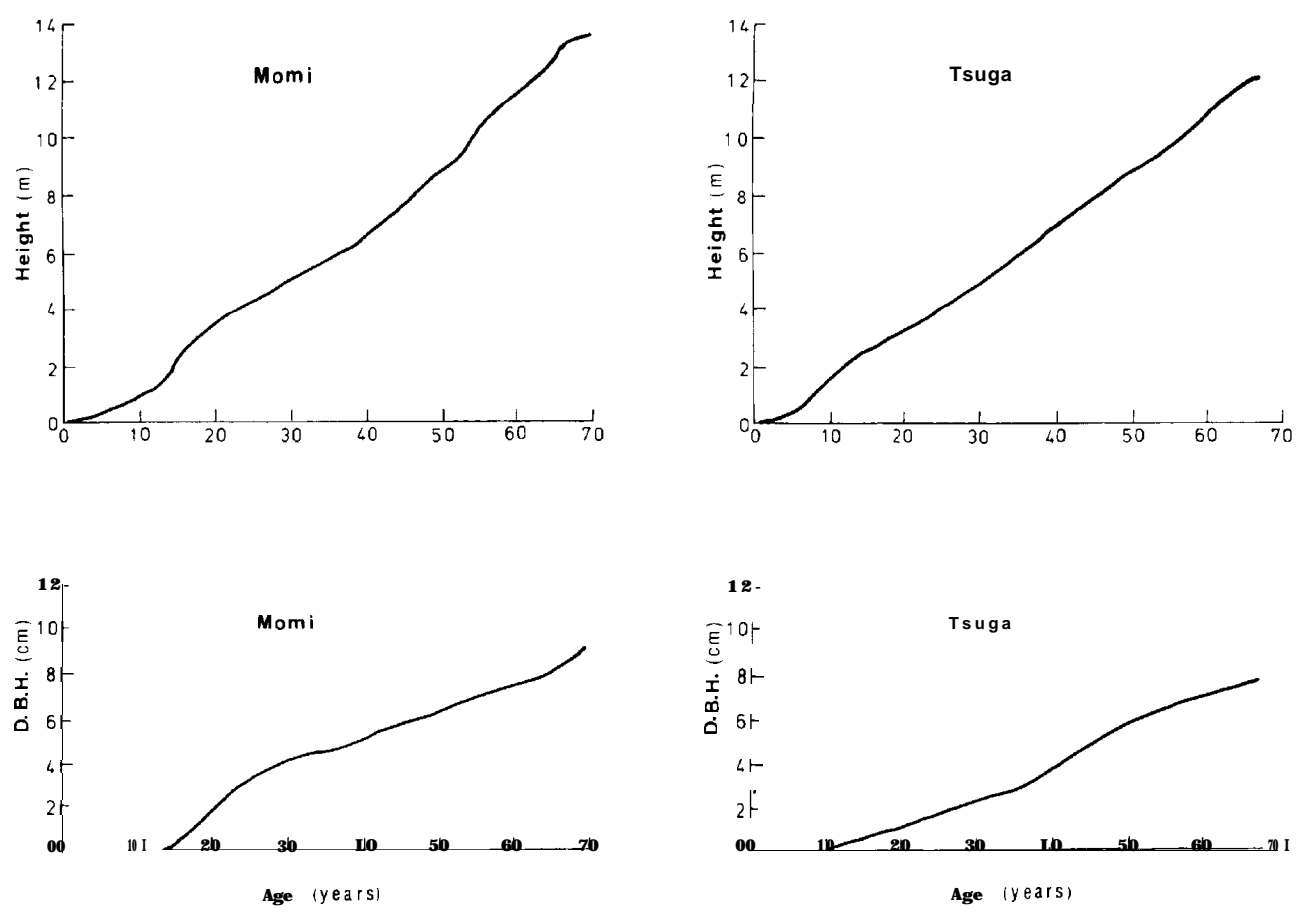

Fig. 1. Growth curves of the trees investigated.

the trees investigated were analyzed at regular intervals. To investigate the distribution of the root, the soils from the surface to a $40-50 \mathrm{~cm}$ depth in the plot were removed by watering. The annual ring analysis were carried out on the main roots.

\section{Results and Discussion}

1) Height and Diameter of stem

Figure 1 shows the growth of height and diameter of the trees surveyed. Momi and tsuga trees had both grown normally. The growth stagnation was not recognized for either tree at the time surveyed.

\section{2) Annual rings of roots}

The more the lateral roots of momi tree were nearer the branching point from the taproots, the more eccentric the diameter growth was. It is very difficult to count exactly the number of annual rings in the atrophied part, because of the existence of the narrow and incomplete annual rings. This brings about a large difference in the number of annual rings between the hypertrophied part and atrophied part. Figure 2 shows the changes of the width of the annual rings in a momi root. The difference in the numbers of annual rings was at a maximum of 8 among radius $\mathrm{A}, \mathrm{B}, \mathrm{C}$ and $\mathrm{D}$. Judging from the fluctuations of the annual ring width, rings $a_{1}, b_{1}, c_{1}$ and $d_{1}$ were 

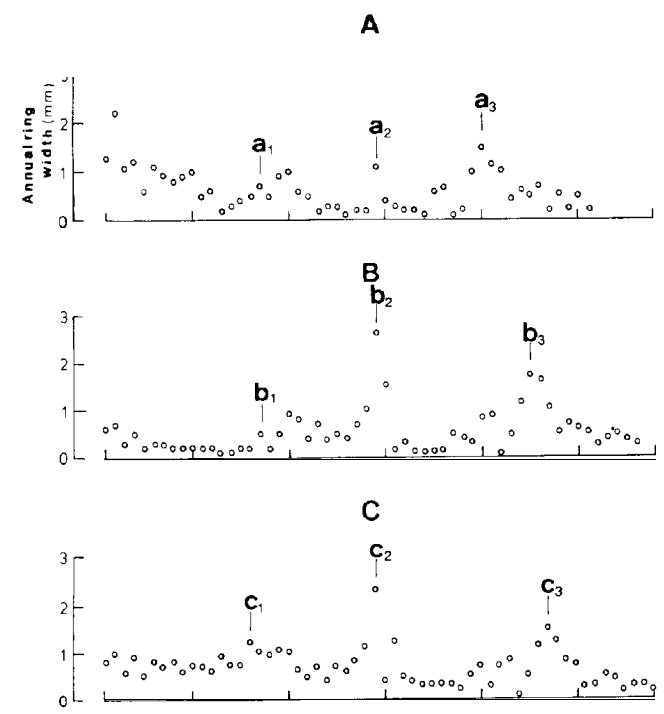

D

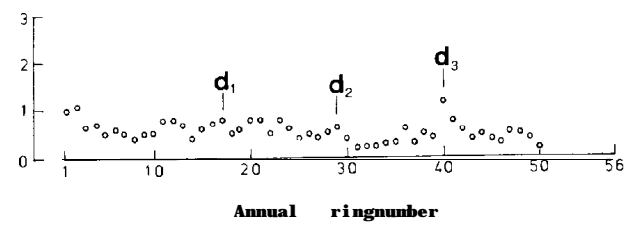

Fig. 2. Changes in annual ring widths of a momi lateral root. A-D : four radii annual ring widths were measured on. Annual ring number : numbered from the outermost ring to the inmost.

regarded as the same ring. Rings $\mathrm{a}_{2}, \mathrm{~b}_{2}, \mathrm{c}_{2}$ and $\mathrm{d}_{2}$ also were regarded as the same ring. On the other hand, the positions of $a_{3}, b_{3}, c_{3}$, and $d_{3}$ are largely different among them. However, the pattern of fluctuation suggest that they also were formed in the same year. This phenomenon has indicated the existence of incomplete annual rings. That is, judging from these phenomena, it seems that most of the incomplete annual rings of momi roots are not the false annual rings but the undistinguished normal rings. Concerning the annual ring of a root, Karizumi (1979) reported that it is necessary to be careful about the distinction between a normal ring and false ring, because annual rings of a root frequently include an incomplete normal annual ring and an annual ring formed by one cell layer. On the other hand, we could recognized only few incomplete annual rings in the tsuga roots.

3) Growth of roots and stems

Figure 3 shows the changes in annual ring widths of momitaproot and stems. It is judged that projected annual rings $r_{2}$ and $s_{2}$ in the figure were formed in the same year. The same is the case between $r_{3}$ and $s_{3}$. Furthermore, the growth course in 


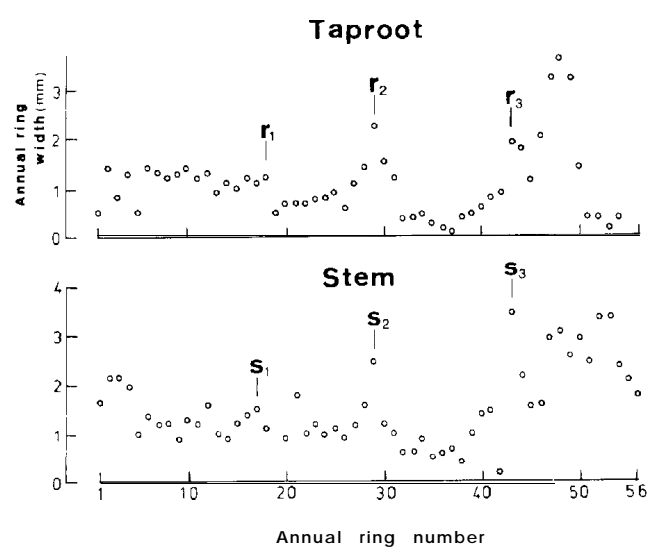

Fig. 3. Changes in annual ring widths of momitaproot and stem. Annual ring widths of taproot were measured at $1.0 \mathrm{~m}$ depth and those of stem at $1.3 \mathrm{~m}$ height. Annual ring number : the same as in Fig. 2.

Fig. 3 is similar to course $\mathrm{C}$ in Fig. 2. These phenomena indicate that the taproot growth of the momi tree is mutually related to the stem growth as in sugi (Cryptomeria japonica) (Shibata, 1935).

On the other hand, the growth relation between the stems and roots was not so clear in the tsuga roots.

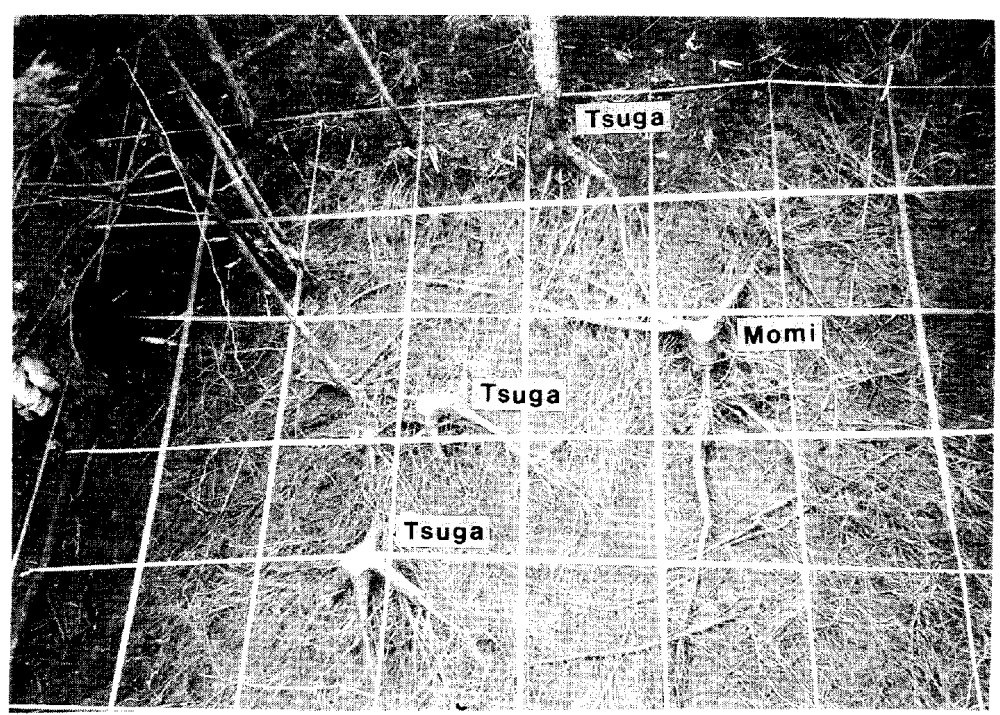

Photo. 1. Distribution of roots. 


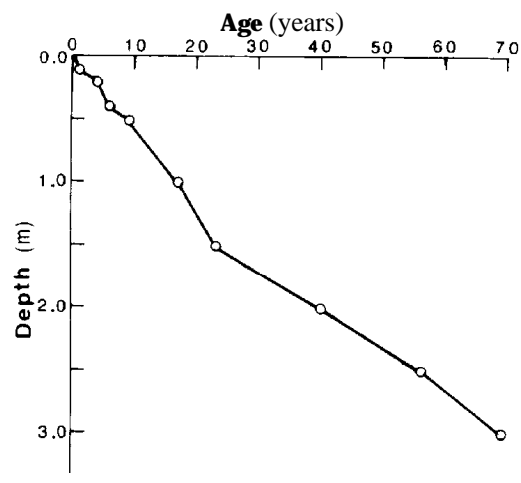

Fig. 4. Growth of momitaproot.

4) Development of root system

In general, it is said that momi trees have a deep root system, and tsuga trees, a shallow root system. As shown in Photo. 1, most of the roots of the momi and tsuga trees had roots extended to a depth of $50 \mathrm{~cm}$ from the surface of the ground, except for the momitaproot which extended to a depth of more than $3.0 \mathrm{~m}$ as shown in Fig. 4. Obviously, the roots of the momi and tsuga trees have crossed each other. Figure 5 shows the growth of lateral roots of momi and tsuga trees. It was not able to show the full length in the absence of the tips for momi lateral roots. There were a considerable difference in the speed of elongation between the momi roots and tsuga roots, that is, the maximum elongation for ten years were $1.8 \mathrm{~m}$ for tsuga and $2.9 \mathrm{~m}$ for momi as shown in this figure. Based on Fig. 5, the developing processes of the root systems were drawn as in Fig. 6. This figure shows the horizontal development of the lateral roots of momi and tsuga trees at 20,40 and 69 years after the momi tree appeared. The tsuga tree appeared two years after the momi tree. Forty years after the appearance of momi tree, the roots of both tress had not crossed. However they had crossed by 69 years. This indicates that the habitat segregation did not occur between momi and tsuga roots.

\section{REFERENCES}

Aragami, K. 1987 Studies on the process of formation of Abies and Tsuga natural forest in the central mountain district of Kyushu. Bull. Kyushu Univ. For., 57: 17-108 (in Japanese with English summary)

Karizumi, N. 1979 Illustration of tree roots. Seibundoshinkosha, Tokyo (in Japanese)

Shibata, N. 1935 On the rootsystem of sugi (Cryptomeria japonica D. Don). 1. The rootsystem of planted sugi tree. J. Jpn. For. Soc., $17: 591-619$ (in Japanese)

Yuruki, T. and K. Aragami 1973 Studies on natural regeneration of Momi (Abies firma S. et Z., Japanese fir) and Tsuga (Tsuga sieboldii Carr., Japanese hemlock). Bull. Kyushu Univ. For., 47 : 77-124 (in Japanese with English summary)

Yuruki, T. and K. Aragami 1987a The development of Momi and Tsuga forest on the basis of diameter growth. J. Jpn. For. Soc., $69: 478-481$

Yuruki, T., K. Aragami and T. Marutani 1987b The develop ment of a small group of Momi (A bies 

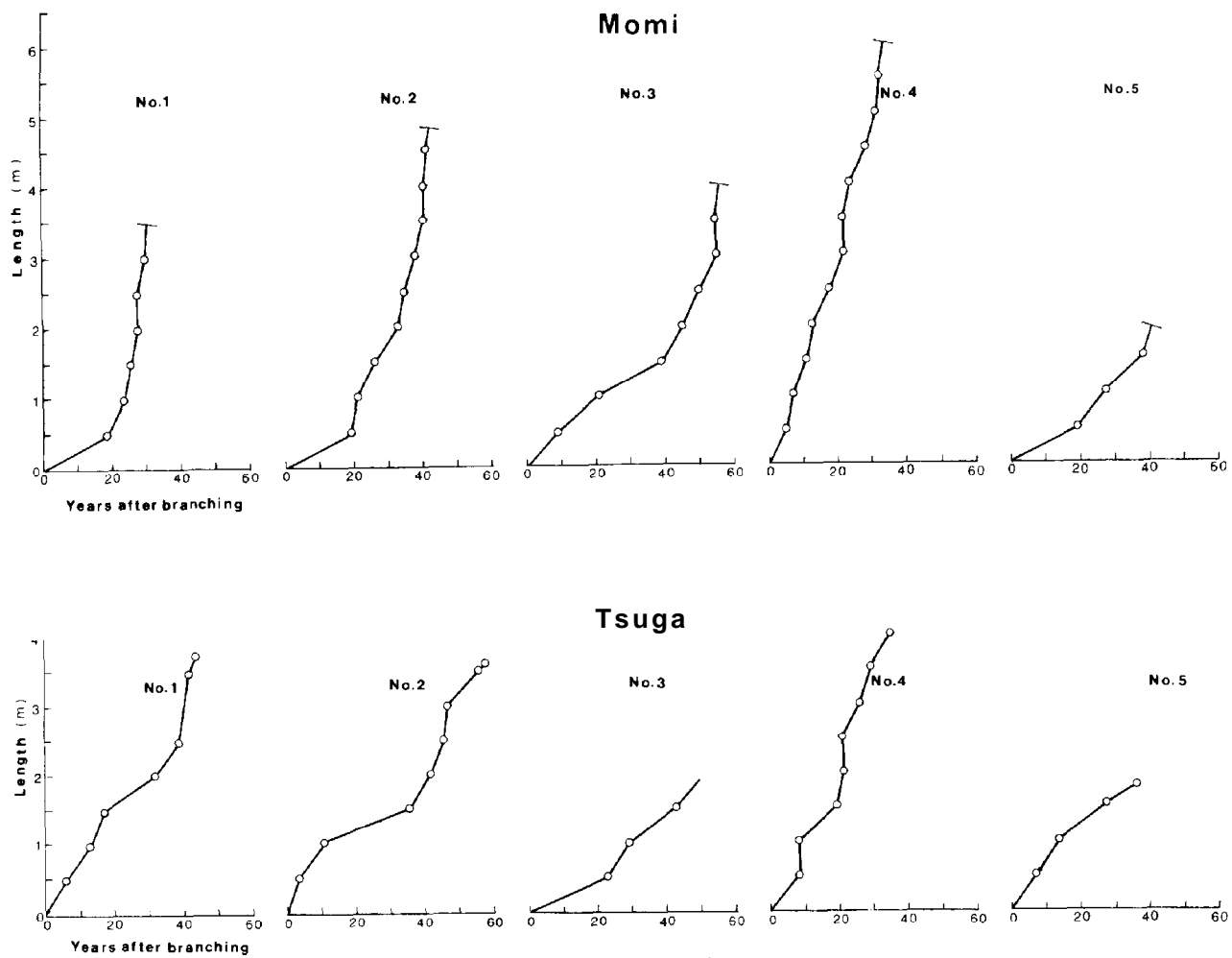

Fig. 5. Growth of lateral roots of momi and tsuga trees.

firma) and Tsuga (Tsuga sieboldii) on the basis of diameter and height growth. J. Fac. Agr., Kyushu Univ., 31(4) : 411-415

Yuruki, T. and K. Aragami 1988 The development of Momi and Tsuga forest. The influence of broad-leaved trees on the growth of two dominant conifers, Momi and Tsuga trees. Bull. Kyushu Univ. For., 59 :1-11 


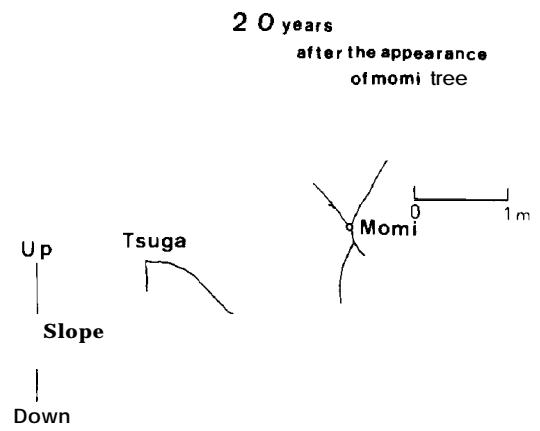

40 years
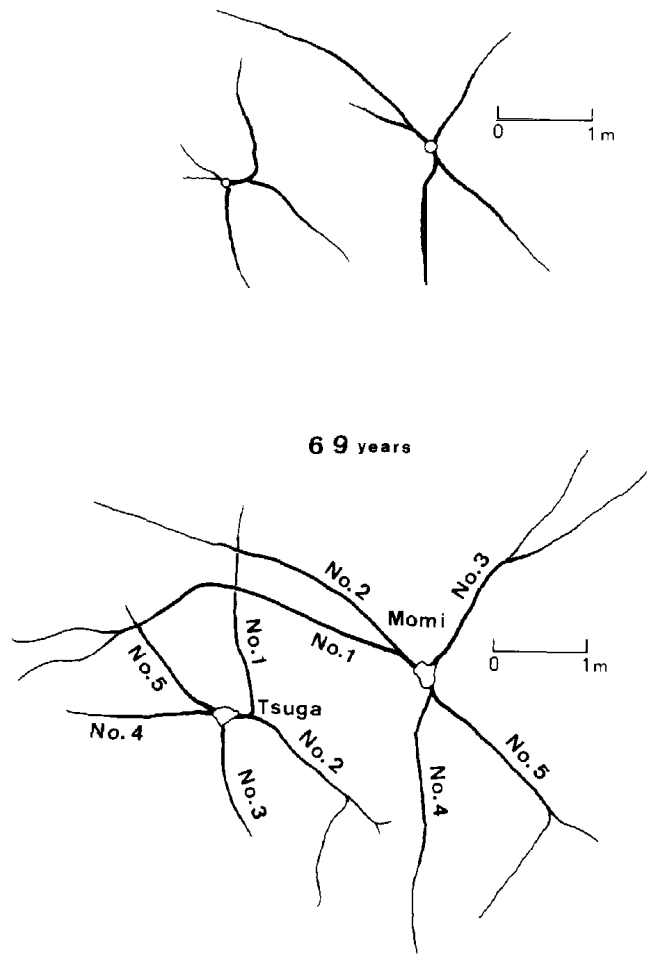

Fig. 6. Horizontal development of lateral roots of momi and tsuga trees. No. : correspond to those in Fig. 5. 